aged by crows. From these estimates, we calculated a 3 to $4 \%$ loss in production, about 40 pounds per acre, for those returning the survey. In estimating overal loss, average losses in the range of 1 to $5 \%$ and 6 to $10 \%$ were reported by $28 \%$ and $26 \%$ of the growers, respectively; $24 \%$ of the growers indicated losses in the range of 11 to $50 \%$.

\section{Control methods used}

Growers were asked to rate the methods used to control bird pests. Of all of the measures used to frighten or disperse birds, shooting was the most common, followed by gas cannons (propane exploder), hawk kites (kites that look like predatory birds) and electronic noise makers (AV-Alarm). Shooting and gas cannons were rated by $47 \%$ and $40 \%$ of the growers, respectively, as giving slight control; $25 \%$ and $32 \%$, respectively, said shooting and gas cannons moderately controlled crows. Trapping, netting, recorded bird calls and bird bombs were also used. Asked how much they would be willing to spend to reduce crow damage in their orchards by $50 \%$, growers gave responses ranging from $\$ 0$ to $\$ 100$ per acre, with an average of $\$ 24.46$ per acre.

Asked to list environmental conditions near their orchards that they felt contributed to crow problems, growers commonly listed tall trees and water sources as contributing to specific bird problems. In addition, wooded areas, brushlands and power lines were associated with crow problems.

\section{Conclusion}

Among birds, crows reportedly cause the most damage to almonds and other crops throughout Sutter and Yuba counties. Magpies are the second most detrimental bird species reported, closely followed by blackbirds, starlings and scrub jays. Bird damage is believed to be getting worse each year in some orchards, as a result of increased bird numbers.

Control methods vary, depending on their cost effectiveness. To reduce damage by $50 \%$ in their orchards, almond growers are willing to spend an average of $\$ 24.46$ per acre, far less than the potential value of nuts lost to such damage. The most effective deterrent appears to be shooting, followed by gas cannons (propane exploders). No control apparently gives excellent results consistently and no improved alternative has been found.

J. Hasey is Farm Advisor, Sutter-Yuba counties, and T. P. Salmon is Extension Wildlife Specialist, Department of Wildlife and Fisheries Biology, UC Davis.

\title{
Berber orchardgrass tested as cover crop in commercial vineyard
}

\author{
James A. Wolpert $\square \quad$ Phil A. Phillips $\square \quad$ R. K. Striegler \\ Michael V. McKenry $\square$ John H. Foott
}

\section{A Berber orchardgrass cover crop reduced the growth and yield of Cabernet Sauvignon grapevines. Some nematode and arthropod pest populations were signiff- cantly lower in the cover crop plots; one was higher.}

Increasing interest in the use of cover crops in commercial viticulture prompted a field experiment which demonstrated that a Berber orchardgrass cover crop can severely reduce grapevine growth and yield, alter vine water status and influence pest population.

The recent attention to vineyard cover crops can be attributed to their ability to moderate vine growth under high fertility conditions, to reduce erosion, to improve soil tilth and to aid integrated pest management goals by harboring beneficial arthropod predators or parasites. Before cover crop use can be recommended, however, the competition of cover crops with vines under various cultural practices needs study as does the possibility of potential encouragement of injurious pests.

\section{Trial conditions}

The trial area was a 26.7-acre, mature, own-rooted Cabernet Sauvignon vineyard located about 8 miles southeast of Santa Maria in Santa Barbara County. The vineyard was planted on a 7-foot by 12-foot spacing (vine by row). In late 1987 , Berber orchardgrass was sown in the inter-row middles, in four blocks of 12 middles each; a 2-foot strip under the vines was kept clean with herbicide applications. Treatment blocks alternated with four 12-middle blocks of clean cultivation that were maintained by regular discing and dormant-season herbicide applications in a 2-foot strip under the vine rows. Wide plots were designed to restrict, as much as possible, pest migration from one treatment to another.

This production area is noted for relatively low winter rainfall and vines are irrigated during the growing season by overhead sprinkler. The total water (winter rainfall plus irrigation) received in the control plots was 18.8 inches $(13.0$ plus 5.8 ) in $1988,19.0$ inches $(10.4$ plus 8.6 ) in 1989 and 17.1 inches (9.1 plus 8.0) in 1990. The Berber cover plots received identical irrigation applications, except in 1990 when they received 3 inches of additional irrigation, bringing the total water received in cover treatments to 20.1 inches. No fertilizer was applied to the experimental area, except in 1990 when the Berber plots received 45 pounds of actual nitrogen as UAN-32 (urea and ammonium nitrate.)

Vines were trained to a two-wire vertical trellis with wires located at about 42 inches and 60 inches above the soil. Vines were cordon-trained on the lower wire and pruned to a combination of 10 to 12 two-bud spurs and four 12- to 15bud canes. Canes were wrapped and tied to the upper wire. At the start of the experiment, vines were considered excessively vigorous and were yielding low amounts of poor quality fruit. The cover crop was being investigated for its potential to reduce excessive vine vigor and thus improve bud fruitfulness and vine yield.

In one of the three center rows of each 12-row block, 10 contiguous vines were selected for uniformity of growth and were marked as data vines for the course of the experiment. Data were recorded, beginning with the harvest in 1988 and continuing for 2 years. Grapevines were individually hand-harvested, clusters were counted and per-vine weights recorded. Before harvest, a single 100-berry sample per treatment replicate was taken and weighed to determine average berry weight. The sample was crushed and juice was analyzed for sugar concentration ( $\left.{ }^{\circ} \mathrm{Brix}\right)$, titratable acidity (TA) and $\mathrm{pH}$. During the subsequent dormant season, vines were pruned and the weight of cane prunings recorded.

During the 1990 growing season, monthly measurements of vine water 
TABLE 1. Effect of Berber orchardgrass cover crop on growth, yield and fruit quality indices of Cabernet Sauvignon grapevines

\begin{tabular}{|c|c|c|c|c|c|c|c|c|c|}
\hline Year & Treatment & $\begin{array}{c}\text { Pruning } \\
\text { weight/ } \\
\text { vine }\end{array}$ & $\begin{array}{l}\text { Yield/ } \\
\text { vine }\end{array}$ & $\begin{array}{l}\text { Clusters/ } \\
\text { vine }\end{array}$ & $\begin{array}{l}\text { Cluster } \\
\text { weight }\end{array}$ & $\begin{array}{l}\text { Berry } \\
\text { weight }\end{array}$ & ${ }^{\circ}$ Brix & $\%$ TA & $\mathrm{pH}$ \\
\hline & & \multicolumn{3}{|c|}{$\ldots \ldots \ldots \ldots$} & \multicolumn{3}{|c|}{.................. $g m$} & & \\
\hline 1988 & $\begin{array}{l}\text { Clean cultivated } \\
\text { Berber cover }\end{array}$ & $\begin{array}{l}6.8 \mathrm{a} \\
7.0 \mathrm{a}\end{array}$ & $\begin{array}{l}11.4 \mathrm{a} \\
11.2 \mathrm{a}\end{array}$ & $\begin{array}{l}132 \mathrm{a} \\
128 \mathrm{a}\end{array}$ & $\begin{array}{l}39 a \\
40 a\end{array}$ & $\begin{array}{l}0.99 \mathrm{a} \\
1.05 \mathrm{a}\end{array}$ & $\begin{array}{l}21.8 \mathrm{a} \\
22.0 \mathrm{a}\end{array}$ & $\begin{array}{l}0.68 \mathrm{a} \\
0.69 \mathrm{a}\end{array}$ & $\begin{array}{l}3.77 \mathrm{a} \\
3.72 \mathrm{a}\end{array}$ \\
\hline 1989 & $\begin{array}{l}\text { Clean cultivated } \\
\text { Berber cover }\end{array}$ & $\begin{array}{l}5.4 \mathrm{a} \\
2.5 \mathrm{~b}\end{array}$ & $\begin{array}{l}9.2 \mathrm{a} \\
7.8 \mathrm{a}\end{array}$ & $\begin{array}{l}89 a \\
77 a\end{array}$ & $\begin{array}{l}45 a \\
45 a\end{array}$ & $\begin{array}{l}1.08 \mathrm{a} \\
0.96 \mathrm{a}\end{array}$ & $\begin{array}{l}20.6 \mathrm{a} \\
21.1 \mathrm{a}\end{array}$ & $\begin{array}{l}0.57 \mathrm{a} \\
0.53 \mathrm{a}\end{array}$ & $\begin{array}{l}3.68 \mathrm{a} \\
3.74 \mathrm{a}\end{array}$ \\
\hline 1990 & $\begin{array}{l}\text { Clean cultivated } \\
\text { Berber cover }\end{array}$ & $\begin{array}{l}4.3 \mathrm{a} \\
1.8 \mathrm{~b}\end{array}$ & $\begin{array}{r}14.0 \mathrm{a} \\
6.6 \mathrm{~b}\end{array}$ & $\begin{array}{l}128 \mathrm{a} \\
102 \mathrm{a}\end{array}$ & $\begin{array}{l}50 a \\
28 b\end{array}$ & $\begin{array}{l}0.83 \mathrm{a} \\
0.54 \mathrm{~b}\end{array}$ & $\begin{array}{l}21.6 \mathrm{~b} \\
26.6 \mathrm{a}\end{array}$ & $\begin{array}{l}0.51 \mathrm{a} \\
0.45 \mathrm{a}\end{array}$ & $\begin{array}{l}3.84 \mathrm{a} \\
3.92 \mathrm{a}\end{array}$ \\
\hline
\end{tabular}

TABLE 2. Effect of Berber orchardgrass cover crop on water relations of Cabernet Sauvignon grapevines, Bien Nacido Vineyards, Santa Maria, $1990^{*}$

\begin{tabular}{|c|c|c|c|c|}
\hline $\begin{array}{l}\text { Sample } \\
\text { date }\end{array}$ & Treatment & $\begin{array}{c}\text { Leaf } \\
\text { water } \\
\text { potential }\end{array}$ & $\begin{array}{c}\text { Stomatal } \\
\text { conductance }\end{array}$ & Transpiration \\
\hline & & $M P a$ & \multicolumn{2}{|c|}{............... $\mathrm{mmol}^{-2} \mathrm{sec}^{-1}$} \\
\hline 22 June & $\begin{array}{l}\text { Clean cultivated } \\
\text { Berber cover }\end{array}$ & $\begin{array}{l}-0.39 a \dagger \\
-0.50 \mathrm{~b}\end{array}$ & $\begin{array}{l}188.6 \mathrm{a} \\
123.3 \mathrm{~b}\end{array}$ & $\begin{array}{l}4.16 \mathrm{a} \\
2.95 \mathrm{~b}\end{array}$ \\
\hline 13 July & $\begin{array}{l}\text { Clean cultivated } \\
\text { Berber cover }\end{array}$ & $\begin{array}{l}-0.46 a \\
-0.64 b\end{array}$ & $\begin{array}{l}64.5 \mathrm{a} \\
40.7 \mathrm{~b}\end{array}$ & $\begin{array}{l}2.57 \mathrm{a} \\
1.46 \mathrm{~b}\end{array}$ \\
\hline 14 August & $\begin{array}{l}\text { Clean cultivated } \\
\text { Berber cover }\end{array}$ & $\begin{array}{l}-0.61 \mathrm{a} \\
-0.77 \mathrm{~b}\end{array}$ & $\begin{array}{l}83.4 \mathrm{a} \\
91.3 \mathrm{a}\end{array}$ & $\begin{array}{l}1.83 \mathrm{a} \\
1.39 \mathrm{a}\end{array}$ \\
\hline 10 September & $\begin{array}{l}\text { Clean cultivated } \\
\text { Berber cover }\end{array}$ & $\begin{array}{l}-0.88 a \\
-0.93 a\end{array}$ & $\begin{array}{l}31.5 \mathrm{a} \\
31.0 \mathrm{a}\end{array}$ & $\begin{array}{l}0.80 \mathrm{a} \\
0.81 \mathrm{a}\end{array}$ \\
\hline
\end{tabular}

Data collected on recently matured, healthy leaves from primary shoots.

$\dagger$ Means followed by the same letter are not significant at $P \leq 0.05$.

TABLE 3. Effect of Berber orchardgrass cover crop on arthropod pests of Cabernet Sauvignon grapevines, Bien Nacido Vineyards, Santa Maria, 1988 and 1989

\begin{tabular}{|c|c|c|c|c|c|}
\hline \multirow[b]{2}{*}{ Year } & \multirow[b]{2}{*}{ Treatment } & \multicolumn{4}{|c|}{ Pest } \\
\hline & & $\begin{array}{c}\text { Grape } \\
\text { leafhopper }\end{array}$ & $\begin{array}{l}\text { flower } \\
\text { thrips }\end{array}$ & $\begin{array}{l}\text { Willamette } \\
\text { mite }\end{array}$ & $\begin{array}{l}\text { Cane } \\
\text { borer }\end{array}$ \\
\hline \multirow[t]{2}{*}{1988} & Clean cultivation & $24.2 \mathrm{a} * 9$ & $130.5 a^{*}$ & $42.0 \%$ af & - \\
\hline & Berber cover & $20.4 b$ & $138.6 \mathrm{a}$ & $22.9 \% \mathrm{~b}$ & - \\
\hline \multirow[t]{2}{*}{1989} & Clean cultivation & 315.7 at & 423.6 at & 0 & $2 b \S$ \\
\hline & Berber cover & $86.5 \mathrm{~b}$ & $219.4 b$ & 0 & $11 \mathrm{a}$ \\
\hline
\end{tabular}

*Average number of individuals trapped per 3×5-inch yellow sticky coated card per 2-week period from July 22 through September 8; four traps/replicate and four replicates/treatment (grape leafhopper, Erythroneura elegantula, and western flower thrips, Frankliniella occidentalis).

†Average number of individuals trapped per 3x5-inch yellow sticky coated card per week from April 6 through October 15; four traps/replicate, four replicates/treatment.

$\ddagger$ Percentage of mid-cane leaves with presence of Willamette mite, Eotetranychus willametti (10 leaves/ sample location and four locations/replicate). Predaceous mite numbers were too low to be of consequence (i.e., $\leq 0.01 /$ leaf)

§Total cane borers, Polycaon confertus, emerged from $3 / 8^{-}$to $1 / 2$-inch diameter prunings collected late February from 10 vines/location, four locations/replicate and four replicates/treatment and placed inside emergence cages at each location.

ๆStatistical separations are within a given year; means followed by the same letter are not significant at $\mathrm{P} \leq 0.05$ status, including stomatal conductance and transpiration, were made with a LiCor porometer. Leaf water potential was also determined by Arimad pressure bomb. The pressure bomb readings were taken between 0700 and 0900 hours local time and completed before the dissipation of morning coastal fog; porometer readings were taken at 1200 to 1400 hours, about solar noon.

\section{Effects seen}

In 1988, the first growing season, the Berber cover was becoming established and no effect was seen (table 1). However, in 1989 the cover crop reduced growth of the Cabernet vines by $54 \%$, and in 1990 it reduced both growth and yield by $58 \%$ and $53 \%$, respectively. In 1990 the effect of Berber cover was still seen, despite the additional 3 inches of irrigation and 45 pounds of actual nitrogen per acre applied differentially to the Berber plots. Without the supplemental water and fertilizer, vines in the Berber treatment would likely have shown even poorer performance.

The effect of the Berber cover crop on vine performance was due, at least partly, to vine water status (table 2). Vines in the cover crop treatment showed greater water stress; that is, lower leaf water potential, stomatal conductance and transpiration early in the season during the grand period of growth. Later in the season, when water is generally withheld to facilitate ripening, vines in both cover and control plots showed equivalent water status.

Pest presence in the vineyard was generally low. However, in 1988, Willamette mite populations were higher in the disced plots and in 1989, leafhopper and thrips populations were higher in the disced plots whereas cane borers were higher in the Berber plots (table 3). No effect was seen on the incidence of powdery mildew or botrytis bunch rot (data not shown). Increased activity of pocket gophers in the Berber cover plots was noted, but the effect could not be quantified (data not shown).

In a study conducted at the Kearney Agricultural Center in 1989, Berber orchardgrass was found to be an excellent nongalling host for root knot nematodes, Meloidogyne spp.; M. incognita produced 497 juveniles/gm of root, $M$. javanica produced 177 juveniles/gm of root, and $M$. arenaria yielded 268 juveniles/gm of root. Berber was a poor host for $M$. hapla, supporting only 0.4 juveniles/gm of root. 

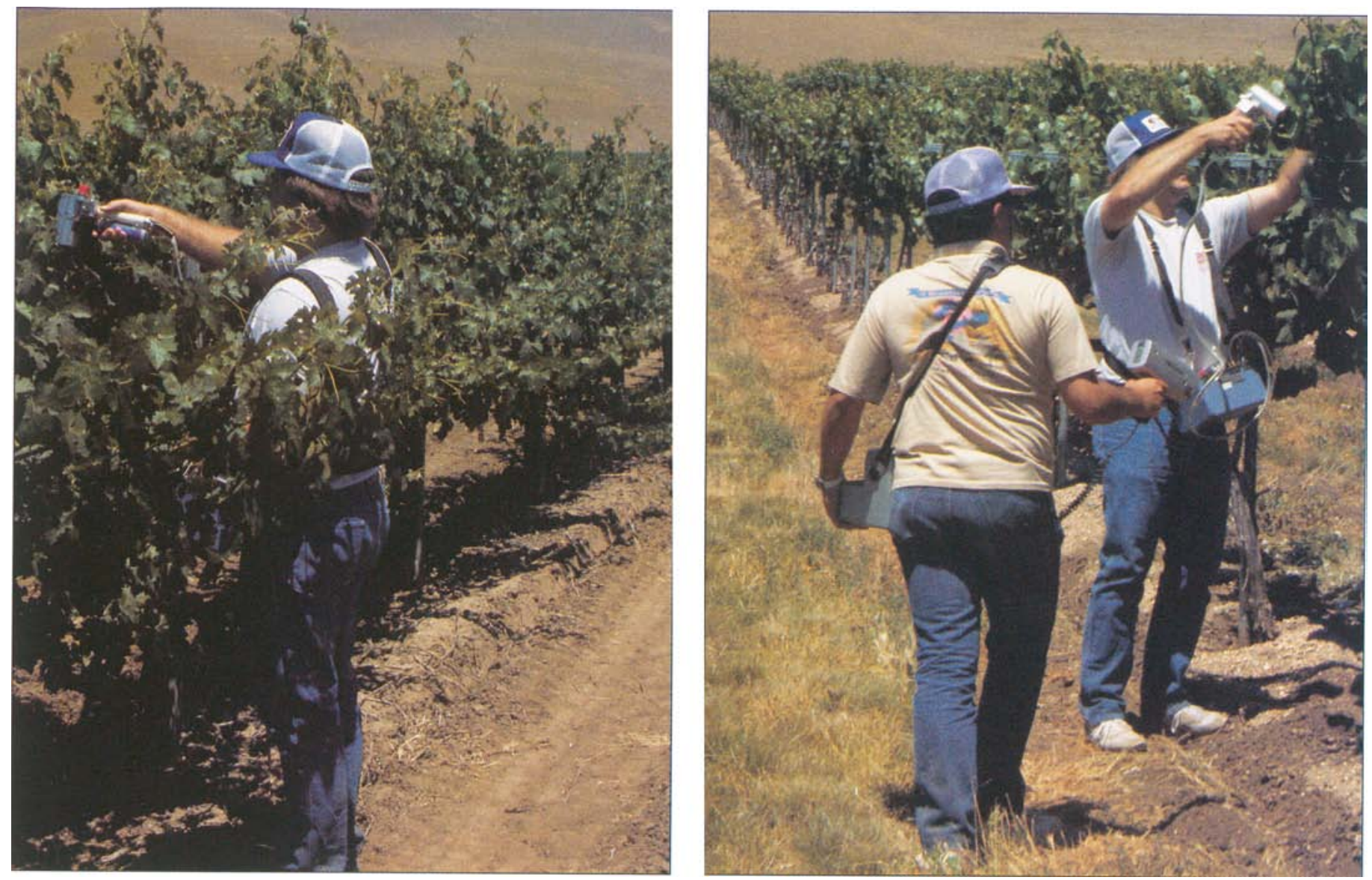

Water status of grapevines was measured in May 1990. Vine vigor differences are apparent between the clean cultivated plots (left) and Berber cover plots (right).

Various Meloidogyne spp. were present in the Santa Maria vineyard. Much of the vineyard was of a finer soil texture and not ideally suited for the buildup of Meloidogyne populations. Soil samples were collected each year of the trial, but an extensive sampling was conducted in fall 1990. A root knot nematode "hot spot" was located across a sandier portion of two of the Berber replicates. Samples were collected along the berms adjacent to where Berber had and had not been grown. Samples were also collected from areas where root knot nematode was not known to occur.

\section{Findings}

The first finding was that Meloidogyne populations did not become more prevalent across the vineyard in spite of the growing of an excellent host, Berber, for 3 years down slope from a high

Meloidogyne population (data not presented). The second finding was that vines grown without Berber cover crops supported higher populations of Meloidogyne, 347 juveniles $/ 250 \mathrm{~cm}^{3}$ soil, whereas vines grown adjacent to Berber yielded 98 juveniles $/ 250 \mathrm{~cm}^{3}$ soil. This statistically significant finding contradicts the previously mentioned host study but supports the notion that vines grown adjacent to the Berber cover were sufficiently reduced in vigor by the competitive effects of Berber to render them less of a food source for root knot nematode. Populations of Dagger nematode, Xiphinema americanum, were also significantly reduced, having a count of $92 / 250$ $\mathrm{cm}^{3}$ soil in the non-Berber area and 39/ $250 \mathrm{~cm}^{3}$ in the Berber area.

\section{Conclusion}

In conclusion, Berber orchardgrass has the potential to greatly reduce the growth and yield of Cabernet Sauvignon and presumably other varieties. However, reduced growth was not accompanied by an increase in desired vine yield. Reduced growth was expected to improve light microclimate and, as a result, improve bud fruitfulness, but this was not the outcome. Deleterious influence of cover crop on vine growth via nutrient competition and allelopathy cannot be ruled out.

Some nematode and arthropod pest populations were significantly lower in the Berber plots. Reduced vine vigor and reduced dust accumulation on foliage may have accounted for the lower arthropod populations in the Berber plots. The appearance of higher cane borer populations in cover crop treatments after only 2 years is of concern. Further investigation of this trend is needed in other sites where permanent covers prevent incorporation of dormant prunings into the soil.

Cover crops are successfully used in coastal vineyards where winter rainfall or irrigation is plentiful and where soils are fertile. However, under the cool climate and low winter rainfall conditions of this experiment in the south Central Coast, Berber orchardgrass cover crop cannot be viewed as a reasonable vine growth management tool without seriously considering other vineyard factors, especially irrigation.

J. A. Wolpert is Extension Viticulturist, Department of Viticulture and Enology, UC Davis; P. A. Phillips is Area IPM Advisor, Ventura; R. K. Striegler is Research Scientist, Viticulture and Enology Research Center, California State University-Fresno; $M$. V. McKenry is Extension Nematologist, UC Riverside and Kearney Agricultural Center; and J. H. Foott is Farm Advisor Emeritus,

San Luis Obispo and Santa Barbara counties.

The authors gratefully acknowledge the support of Bien Nacido Vineyards and the cooperation of vineyard managers Pete Richmond, Kurt Gollnick and Jeff Frey. Partial funding was provided by UC/IPM, Bien Nacido Vineyards and Domaine Chandon, Inc. 